\title{
Attitudes of Media and Political Sciences Students Towards the Way Palestinian \\ Television Addresses the political Division: A Field Study
}

\author{
Ayat Abu Al Own, ALYarmouk University, Jordan \\ Mohammad Al Qudah, AL Yarmouk University, Jordan
}

\begin{abstract}
This study aims at recognizing the attitudes of media and political sciences students towards the way Palestinian Television addresses political division within the framework of several theories, namely: the functional perspective of mass media and the theory of dependence on mass media. To achieve the study objectives, the researchers employed the approach of "surveying the audience of mass media" based on a sample of (400) students chosen by the stratified random sampling from Al-Najah National University in the West Bank and the Islamic University in Gaza.
\end{abstract}

The study has come up with the following results: (62.7\%) of the sample watch Palestine T.V, whereas $(37.3 \%)$ do not. The item related to the evening period of watching T.V gets the highest average value which stands at (1.52). The results also showed that the media most trusted by students in pursuing the Palestinian division is the Palestinian radio stations, the Palestinian press, and then the Palestinian TV.

Keywords: Attitudes of Media, political Division, West Bank, Sector Gaza, Palestine TV 


\section{Introduction}

TV surpasses all information media as it plays an influential role in all walks of life. Its role is not only influential but also formative of a large number of aspects of life. "A person cannot form a particular position or adopt a certain stand except through the information he/she is provided with, confirming the ability of the media in all its forms and manifestations in producing changes in the individual, the community concepts and practices via dissemination of knowledge ,awareness, enlightenment, opinion formation and dissemination of information and other various issues ( Al-Qudah, 2012).

The TV is a platform for the statesmen who through their purposeful speeches aim to extend their messages and convince the public of their policy. Al Qudah believes that the factors which led to the emergence of television in the Arab countries are divided into: "two factors which have their impact on the emergence of television in the Arab countries: On one hand, the TV has become a necessary media for the Arab countries, on the other hand, the Arab rulers understand the effective role of the TV in guiding their people politically and socially."(Qudah, 1998). The TV has its contribution in educating the public on how to express their opinions freely, and how to support the popular and political leaders to achieve their goals. (Al Dosoki, 2004)

As a result of the foregoing discourse, the Arab regimes controlled televisions, and here we see that televisions emerged according to a political decree in most Arab countries. These televisions are characterized by showing rigid, controlled, monotonous articles and official discourse due to the regime inability to appoint professional and experienced personnel. AlDulaimi considered the advent of television in the Arab countries - as a complement to sovereignty, and it is considered as a set in the service of the regime rather than focusing on broadcasting other public appealing programs. (Dulaimi, 2011).

The darkest side - as viewed -by Mashagbeh- lies in the submission of the media to the authority; this is part of the whole society capitulation, when the media gives in, culture and thought regress in the absence of popular will. (Mashagbeh, 2011) 


\section{Problem of the Study}

The problem is limited to identifying the Palestinian university students' attitudes towards the way Palestinian television handles the problem of the Palestinian political division, through a sample of media and political sciences students.

\section{Significance of the Study}

The study significance springs from the following:

- Scarcity of media studies concerned with identifying university youth attitudes towards the way the Palestinian media addresses the Palestinian political division. This study explores the views of a sample of students on this issue.

- Regular scientific investigation of a sample of the Palestinian public trends towards the way the Palestinian TV treats the political division.

\section{Objectives of the Study}

The study aims at identifying the university youth attitudes towards Palestinian television while handling the political division in the occupied Palestinian territories. As part of the study, the researchers seek to achieve the following sub-goals:

1. Identifying the exposure rate of the respondents to the Palestinian Television; the motives of this exposure; its causes and effects.

2. Recognizing the status of the Palestinian television amongst other media as a source of information about the cause of division.

3. Monitoring the respondents' views in the way Palestine TV handles division.

4. Getting acquainted with the credibility degree of the Palestinian television enjoys as a reliable source of information on the issue of political division.

5. Monitoring the presence of relationship between the characteristics of respondents, the level of confidence in television as a source of information on national issues like the political division.

\section{Questions of the Study}

1-Which television programs showed more interest in the political division?

2- To what extent did the Palestinian TV show commitment to display all different opinions on the issue of political division? 
3-What are the views of respondents regarding the television handling of the Palestinian political division, and the impact of the Palestinian division on the priorities that the Palestinian public care about?

4- What are the attitudes of the public towards the role played by the Palestinian television while addressing the political division?

5- What are the respondents' attitudes towards the Palestinian television while addressing the political division?

6- What is the status of Palestinian television as a source of information for the public on the political division as compared with the rest of the other media?

7- What are the resulting effects of the public dependence on the Palestinian television as a source of information on the issue of the political division?

8- What degree of dependence given by respondents for the Palestinian television when exposed to contradictory information, or difficult to understand, and how to obtain other information about the Palestinian division?

\section{Hypotheses of the Study}

1. Are there significant statistical differences at $\alpha<0.05$ among the study variables (reliability, attitudes, TV role, priorities and confidence) related to the study variables (sex, specialization, residence, political affiliation)

2. There is a significant statistical relationship between residence and political affiliation at $\alpha<0.05$

3. There is a significant statistical relationship among the study variables (age, specialization, residence and political affiliation) at $\alpha<0.05$.

4. There is a significant statistical relationship among the study variables (age, specialization, residence and political affiliation) and reliance on the Palestinian TV when it shows contradictory information regarding the Palestinian division at $(\alpha<0.05)$.

5. There is a significant statistical relationship among the study variables (age, specialization, residence and political affiliation) and reliance on the Palestinian TV when obtaining information regarding the Palestinian division at $(\alpha<0.05)$.

6. There is a significant statistical relationship among the study variables (age, specialization, residence and political affiliation) and reliance on the Palestinian TV in understanding topics related to political division at $(\alpha<0.05)$. 
7. There are significant statistical differences between degree of confidence in the TV as source of information on the issue of division according to the respondent's sex at $(\alpha<0.05)$.

\section{Theoretical Framework}

First: Attitudes- Concept -Types- Measurement

Bugardes defines attitude as that tendency which leads behavior close to some environmental factors or away from them. It also gives them positive or negative criteria for their attraction to ordistastes them. (Fibanse, 2000). An attitude may be negative, neutral, weak, or strong regarding a particular thing. (Mohammed, 2012)

Second: kinds of attitudes

General, special, individual, collective, public and secret attitudes (SayyedFouad Al -Bahi, 2009).

Third: Measuring Attitudes: means transforming attitudes from the descriptive formula as follows: Agree or disagree; or pro or against to a quantitative formula by which comparison between universities or individuals can be compared with each other's (SayyedFouad AlBahi, 2009). One of the most important metrics used to measure scientific attitudes is: the functional perspective of media.

There are several functions for the media in the community; in this context, (Wilbur Schramm) presented three general functions he viewed as necessary for public interaction:

Observer's function, political function and upbringing function. The media serve the community in many ways; directly and indirectly. All leaders and citizens cannot communicate except by using the media. Thus, the media are vital in the dissemination of good information from the government to all citizens. (Makkawi, 2003) says that the term "structuralism" or "structure" refers to the way the community regulates its repeated activities. As for the term "function" it refers to the contribution of certain forms of repetitive activities in maintaining continuity of balance in the society. Melvin indicates that some stereotyped processes in society are characterized by determinism, (Melvin for 1994). Modern societies are made up of different units, and mass communication is considered one of the components of modern societies; so the job of these units is to do repetitive actions to maintain the stability of the society. The media is one of the basic and indispensible components of contemporary societies. 


\section{Relying on the Media}

The theory of interdependence started through the motives of the social school, where the supporters of this theory consider that there is a common link based on the interdependence between the mass media and social system. The concept of the theory among individuals and the media springs from the common relationship which is based on reciprocal dependency between media, the social systems and the public. This relationship may exist in all media systems or in one of its parts, as the audience depends on the sources of information to reach their goals. (Mashagbeh, 2001).

The individuals rely on media to achieve the following key objectives:

[1] Understanding. [2] Guidance and counseling; which means directing work for something or making a decision in the context of the society expectations and ethics. [3] Entertainment: which includes isolated entertainment and social entertainment, such as social companionship as a way to escape the problems of everyday life (Malkawi, 2009). The major hypothesis for the model of relying on the media increases with scalable ability to receive the required information through personal sources ,taking into account the abundance and evaluation of the information required; and comparing it with the public personal sources. The more communities become sophisticated, the more individuals depend on the media outside their groups.

\section{Literature Review}

The researchers reviewed some related studies .In this section, the researchers will focus on the studies related to the Palestinian division. A study conducted by Montasser (2012) entitled (the role of media in promoting the Palestinian division, the space channels of Palestine and Al-Aqsa as a model (Montasser, 2012)). The main objective of this study is to highlight the role of the Palestinian media in promoting division with a focus on visual media, specifically the role of the space channels of Palestine and Al-Aqsa; and how both channels dealt with the issue of the Palestinian division. A study conducted by Al Talib (2011) entitled: (the role of the Palestinian media in promoting the national unity among the female college students in the Gaza Strip (Al Talib, 2011). The study showed that $95.9 \%$ of the sample always follows up the Palestinian relations. About $4.1 \%$ sometimes follow up -Palestinian -Palestinian relations. $60.4 \%$ of the study sample believes that the Palestinian media is unable to promote national unity; whereas $20.6 \%$ of the sample believes the Palestinian media promote national 
unity. Some $19 \%$ of the sample believes that the Palestinian media sometimes promote national unity. The study also revealed that $41.3 \%$ of the study sample believes that TV is the best media to strengthen national unity. The study also revealed that $32.9 \%$ of the study sample holding Fatah and Hamas direct responsibility for the Palestinian division (AlTalib, 2011). Um Toman conducted a study (2010) entitled: The Palestinian media and its impact on the political division (2006-2009). The aim of this study is to investigate the impact of the Palestinian media during the political division. A sample of (691) university Palestinian students was involved. The results of the study showed that $22.3 \%$ of the respondents trusted the Palestinian media. $20.88 \%$ of the respondents expressed their confidence in the Arab media. $(15.66 \%)$ of the sample expressed their trust in the foreign media. The results also showed that $(26.9 \%)$ the sample members believe that television is the most effective media .Some $(78.32 \%)$ of the sample believe that media is far from credibility and impartiality. The results also indicated that $(80.7 \%)$ believe that the media has strengthened the Palestinian division. Sodki (2009) conducted a study entitled (Trends of Palestinian university students towards media coverage of the Palestine TV channel of internal events -Birzeit University model) (Sodky 2009).

The most important results of this study showed that students' attitudes are passive regarding the role of the channel during the internal conflict. the study also showed that students relied more on Arab satellite channels, then Arabic-speaking foreign TV satellite, and local radio and television stations (except Palestine and Al-Aqsa channels).The results indicated that there are also significant statistical differences between the students' attitudes towards the media coverage of Palestine Channel for the internal conflict, attributable to political affiliation, college and place of residence variables. A study was carried out by (Al Dalow, 2006) entitled (public Trends towards the means of communication and tactics used in AlAqsa Intifada) (Al Dalow, 2006) .This study aims at identifying the trends of the public towards the means of communication and tactics used in al-Aqsa intifada and detecting the public most important sources of information, media functions and roles, ways of exposure to media and the degree of confidence in the media.

The most important results revealed that modern means of communication are the most favorable to follow Al-Aqsa intifada. Television came in the first place followed by radio and finally newspapers. The study also showed that there is no specific time to follow the media. 
It was found that those who are exposed to media for less than an hour are about $(72.3 \%)$ compared with (44.7\%) who are exposed to media from one to two hours. A Study conducted by Abdullah (2003) on (the impact of the Israeli media on the attitudes of media students of Birzeit University towards "corruption of the Palestinian Authority as a model" (Abdullah, 2003). One of the most important results of this study proved the validity of the first hypothesis: that there is a positive relationship statistically significant between the degree of a student exposure to Israeli media and his/her position regarding the corruption of the Palestinian Authority. (Al- Sari, 2011)

\section{Comment on the Related Studies}

After having a thorough look at the aforementioned studies, The researchers found out that those studies aim at highlighting the importance of media in influencing the public by providing them with information on the political division and national unity. The focus was, of course on the television. One can notice that some of previous studies were interested in studying media such as the study of (Al-Talib - Al-Farra\& Al- Montasser), whereas the study of (Mousa and Abdul Rahim) focused on the attitudes of the public.

The samples of these studies were mainly university students. The current study agrees with the studies of (Mousa and Abdul Rahim, Al-Talib- UmToman, and Al Dalow) in choosing university students as their sample of study.This study disagreed with that of (Mousa) in the sense that most media students relied on following up events of the internal conflict on the Arab satellite channels, then the foreign Arabic-speaking space channels, and local radio and television stations (except Palestine and AL- Aqsa TVs). Whereas this study showed that the media most trusted by students in pursuing the Palestinian division is the Palestinian radio stations, the Palestinian press, and then the Palestinian TV. This study agrees with the study by (Mousa) in that there are significant statistical differences in the students 'attitudes towards the media coverage of Palestine Channel to the events of the internal conflict attributed to political affiliation variable. This study also showed that there are significant statistical differences for the impact of political affiliation on students' attitudes towards the way Palestinian TV addresses the division. This study disagrees with that of (Mousa.). Mousa's study showed that there are significant statistical differences in the students' attitudes towards the media coverage of Palestine Channel for the events of the internal conflict due to the 
residence variable, while the current study showed there were no significant statistical differences due to the place of residence.

\section{Procedures and Methodology}

\section{Limitations of the Study}

The study is limited to temporal and spatial limits: Temporal means the time that the questionnaire will be applied, (the month of May _ April 2012), the spatial limitations, however, are the Palestinian universities (Gaza Strip, West Bank)

1) This study was limited to the media and political science students at the Palestinian universities (West Bank and Gaza Strip)

2) The study instrument is a questionnaire developed to achieve the goals of the study and answer its questions.

3) The results that will be obtained.

This study falls within the descriptive studies which deal with studying the current realities of the phenomenon studied: (Attitudes of university students towards the way Palestinian television addresses the issue of political division).This approach is an organized scientific effort that aims at obtaining information and data about a phenomenon or more to form a basic data base which helps in diagnosing and interpreting phenomena. "(Abdul Hamid, 1993)

\section{Population and Sample of the Study}

The study population consisted of all university students majoring in political science and media in Gaza Strip and the West Bank.The study sample consisted of (400) male and female university students in Gaza Strip and the West Bank in the Department of Political Science and media. Following is a description of the study sample: Members of the study sample by place of residence: (177) from the West Bank, and (223) from the Gaza Strip, Demographic variables: (sex, permanent residence, temporary residence, political affiliation, age, specialization) for all members. The results showed that males who were involved in the study constituted $(49.8 \%)$. This percentage is lower than that of the females which amounted to $(50.3 \%)$; while the city dwellers were (57.8\%); and the villagers formed $(22.3 \%)$; and refugee camps residents represented (20.0\%). As for those residing in the West Bank, they represented (44.3\%); and the percentage of those living in Gaza Strip were (55.8\%). The table also shows that those who are politically independent constituted (50.0\%); and 
partisans $(50.0 \%)$.The table also points out that sample members aging between (17-19) constituted (25.5\%); and those who are (20-22) formed (49.0\%). The sample members who are (23-25) years old represented (19.5); and those who are (26 and older) represented (6.0\%). The table also indicates that the percentage of students in the media both males and females involved in the study amounted to $(67.8 \%)$; while males and females students of political science constituted $(32.3 \%)$.

A Questionnaire was used to collect data regarding students' attitudes towards the way Palestine space channel addresses political division. Political science and media at Al-Najah University in the West and the Islamic University in Gaza were involved.

\section{Validity and Reliability of the Instrument}

To guarantee the instrument validity, the questionnaire was presented to a jury of scholars specialists in Political Science and media.Face validity refers to the appropriateness of the questionnaire in terms of vocabulary, language and clarity. In addition a pre-posttest for the instrument has been administered to a group from outside the study population. The value of reliability Coefficient according to Cronbach alpha is (0.91). This high Value is acceptable for the purpose of this study

\section{Data Analysis}

The SPSS program was used both the descriptive and the analytical as follows:

A) at the descriptive level: calculating frequencies and percentages. -Calculating means and standard deviations.

B) At the analytical level: T-test \& Chi Square $\chi^{2}$ are used to measure the statistical significance among variables. Compatibility coefficient to measure the strength of relationship between the variables one way Anovatest was used.

Rates of Watching Palestinian Television:

The first question: What are the habitual and expediency motives that make the Palestinian public view the Palestinian TV? The results indicated that realizing (what is happening around me) received the highest mean of (.50) and a standard deviation of (0.501);followed by (Learning how people behave in different situations) with a mean of (0.29) and a standard deviation of (.430).Results also showed that the highest mean reached (0.27) and a standard 
deviation of (0.446) in favor of the fun and enjoyable motive, followed by the item "to quickly pass the time" with a mean of (.26) and a standard deviation of (0.437). The second question: What television programs focus on political division more than others?The results showed that "Inside Look" program was ranked first under the variable "very much" by $(27.5 \%)$, while the "news summary" obtained the highest percentage among programs that deal with issues of interest to the public under the variable "very much" by $(32.9 \%)$; the "open talks" program, however, recorded the highest mean of (3.46) and a standard deviation of (1.216).

The third question: "To what extent does the Palestinian television reflect credibility by showing all opinions related to political division?"The results proved that the item which stipulates that "the TV intensively broadcasts news related to the Palestinian Authority more than others" occupied the highest percentage under the variable always by (41.4\%), followed by an item which stipulates that "the TV focuses on news of the Palestinian official figures in the West Bank more than focusing on the official personalities of Gaza Strip" by (39.8\%). The lowest percentage (13.1\%) of the same variable "always" went to the two items which stipulate that "TV presents facts and cares about the interests of the society". Broadcasting news related to division without prejudice to any party got the highest percentage of $(37.8 \%)$, under a variable of "does not enjoy credibility" The table also shows that the item which received the highest mean is the one which stipulates the TV (focuses on the personal news of the official Palestinian figures in the West Bank more than on those in the Gaza Strip).The mean is (2.96) and the standard deviation is (1.037.Both researchers attributed these results to the assumption that the official Palestinian television represents one faction, and all issues are viewed from one perspective.

The fourth question: What are the attitudes of respondents towards the way the Palestinian TV handles the issue of political division and the impact of this division on the priorities and issues the Palestinian television cares about? Firstly: The television treatment of the political division: The results showed that the Palestinian television conveys only the point of view of one faction. This item was ranked first under "strongly agree" variable by $(41.4 \%)$, and under the variable "agree" by $(30.7 \%)$. The table shows that the item which states that "the Palestinian television is an independent media organization won the highest percentage amounted to (34.7) under the variable of "not strongly agree". The table also indicates that 
Palestinian television conveys the point of view of one faction took the highest mean of (3.86) and a standard deviation of (1.252), it is the same item that got the highest percentage. Secondly: The Impact of the Palestinian division on issues of interest to the Palestinian TV.The results indicated that the issue of the Israeli war on the Gaza Strip took the highest percentage $(32.7 \%)$ under "strongly agree" variable and the issue of the daily Israeli practices got the highest percentage (31.1\%) under "I agree" variable. Whereas a theft case of natural resources by the occupying authority got the highest percentage of $(30.3 \%)$ under "strongly disagree" variable. The Israeli war on the Gaza Strip won the highest mean of (3.67) and a standard deviation of (1.196), which is the same issue that got the highest variable under "strongly agree and agree", followed by the electricity and fuel crisis in the Gaza Strip with a mean of (3.47), and a standard deviation of (1.285). The researchers attributed this result to the viewer who lies under the Israeli occupation and he is interested in knowing the latest news in the Israeli-Palestinian conflict. Consequently, it is natural that the viewer follows the war on the Gaza Strip and the circumstances of the siege, in addition to the crisis of electricity and fuel. Thirdly: Priorities of the Palestinian Television. The results showed that resisting the occupation got the highest mean of (3.87) and a standard deviation of (1.221), followed by the issue of refugees with a mean of (3.57) and a standard deviation of (1.219), while The issue of apartheid got the lowest mean amounted to (3.13) and a standard deviation of (1.331). The Fifth Question: "What are the attitudes of the public towards the role played by the Palestinian television towards addressing the issue of political division?"The results showed that the item which states that "the Palestinian television deepens the internal political division" got the highest percentage of (35.1\%) under "Strongly agree" variable; and got the highest percentage of (33.1\%) under the variable "agree". The two items which stipulate that the Palestinian TV fights Palestinian political division and does not care much about the issue of division obtained the highest percentage of (19.9\%), under the variable "disagree", while the item which stipulates that Palestinian TV does not have any role in the issue of Palestinian political division got the highest percentage of (39.8\%), under "strongly agree" variable. The table also indicates that the highest mean (3.80) and a standard deviation of (1.180), went to the first item which states that the (Palestinian TV deepens the division); this is the same item that got the highest percentage under "strongly agree" variable.

The sixth Question: What are the attitudes of the respondents towards the Palestinian Television way of addressing political division?The results showed that the highest 
percentage of $(39.8 \%)$ went to the item which states that Palestinian TV (does not allocate enough space for the political views contrary to that of the authority in Ramallah). The item which stipulates that "the TV does not care to present the political point of view contrary to the Palestinian Authority" was ranked the last with a mean of (17.5) under "strongly disagree" variable. The table shows that the highest mean (3.67) and the standard deviation (1.370) was won by the item which states that Palestinian TV (does not allocate enough space for the political views contrary to the authority's in Ramallah), The Seventh Question: What is the status of Palestinian television as a source of information to the public on the issue of the political division, compared with the rest of the other media outlets? The results showed that the Palestinian TV got the highest confidence amounted to (26.7\%) under "I highly trust it" variable. The Palestinian press got the highest degree of trust by $(26.3 \%)$ of the respondents. One can observe from the table that Palestinian radio took the highest mean of confidence of (4.15) and a standard deviation of (1.369); followed by the Palestinian press with a mean of (4.09) and a standard deviation of (1.301).

The Eighth Question: What effects resulted from the public reliance on Palestinian television as a source of information on the issue of the political division?" The results showed that the highest percentage obtained by the item "my knowledge about the reasons that led to the division increased by a percentage of (28.7\%) under "strongly agree" variable. The item which states "Iam becoming more aware of events experienced by the Palestinian community" got the highest percentage of $(35.1 \%)$ and the item which stipulates that " it made me participate in the dissemination of ideas and opinions" got the lowest percentage by (17.5) under "I agree" variable. The item which stipulates that "my knowledge increased of the reasons that led to the division" came at the lowest rate of (21.9) under "strongly disagree" variable. The table also indicates that the highest mean came in favor of the cognitive effects of the first item, which states: (my knowledge of the reasons that led to the division increased), and got the highest mean of (3.51) and a standard deviation of (1.303). This is the same item that got the highest percentage. The Ninth Question: What degree of reliance that respondents attach to Palestinian television when exposed to contradictory information, or difficult to understand, and how to obtain other information about the Palestinian division?" The results showed that the percentage of those who resort to the Palestinian television when they are highly exposed to contradictory information is $(10.4 \%)$; the percentage of those who have the desire to obtain important information about the division 
under the same variable is $(11.2 \%)$. The percentage under the item of getting exciting information under the same variable came by $(10 \%$,$) . Of course, this is a very serious.$

\section{Testing the Hypotheses}

Testing the first hypothesis: Are there significant statistical differences at $(0<0.05)$ among the study variables (credibility, attitudes, the TV role, priorities and confidence) attributed to the study variables (sex, specialization, place of residence and political affiliation).

\section{First: Sex}

Table 1: shows means, standard deviation, $\mathrm{T}$ test for the impact of sex on the variables.

\begin{tabular}{|c|c|c|c|c|c|c|c|}
\hline Variables & Sex & No. & Means & $\begin{array}{l}\text { Standard } \\
\text { Deviation }\end{array}$ & T Value & $\begin{array}{l}\text { Degrees of } \\
\text { Freedom }\end{array}$ & $\begin{array}{c}\text { Significance } \\
\text { Level }\end{array}$ \\
\hline \multirow[t]{2}{*}{ Credibility } & Male & 140 & 2.48 & 0584 & -0133 & 249 & 0910 \\
\hline & female & 111 & 2.49 & 0556 & & & \\
\hline \multirow{2}{*}{$\begin{array}{c}\text { Attitudes of students } \\
\text { towards the way the } \\
\text { Palestinian TV addresses } \\
\text { the Palestinian division }\end{array}$} & Male & 140 & 3.54 & $\mathbf{0 8 3 7}$ & 0895 & 249 & 0371 \\
\hline & female & 111 & 3.45 & 0795 & & & \\
\hline \multirow[t]{2}{*}{ Role of the Palestinian TV } & Male & 140 & 2.92 & 0760 & -0549 & 249 & 0583 \\
\hline & female & 111 & 2.97 & 0791 & & & \\
\hline \multirow[t]{2}{*}{ Priorities } & Male & 140 & 3.36 & 0904 & -0052 & 249 & 0959 \\
\hline & female & 111 & 3.37 & $\mathbf{0 8 1 7}$ & & & \\
\hline \multirow[t]{2}{*}{ Confidence } & Male & 140 & 3.68 & 0715 & -0831 & 249 & 04 \\
\hline & female & 111 & 3.75 & $\mathbf{0 7 3 3}$ & & & \\
\hline
\end{tabular}

\section{Significance}

Table (1) shows that there are no significant statistical differences at $(0=0.05)$ due to the effect of sex on credibility variable. The value of (T) is (-0113), a value which is not statistically significant at a level less than (0.05). There are no significant statistical differences in all items shown in the table above. 


\section{Second: Specialization}

Table 2: shows Means, standard deviations test for the impact of specialization on the variables.

\begin{tabular}{|c|c|c|c|c|c|c|c|}
\hline Variables & & No. & Means & $\begin{array}{l}\text { Standard } \\
\text { Deviation }\end{array}$ & T Value & $\begin{array}{l}\text { Degrees of } \\
\text { Freedom }\end{array}$ & $\begin{array}{l}\text { Significance } \\
\text { Level }\end{array}$ \\
\hline \multirow[t]{2}{*}{ Credibility } & Media & 172 & 2.42 & .583 & -2.435 & 249 & .016 \\
\hline & $\begin{array}{l}\text { Political } \\
\text { science }\end{array}$ & 79 & 2.61 & .523 & & & \\
\hline \multirow{2}{*}{$\begin{array}{l}\text { Attitudes of students } \\
\text { towards the way the } \\
\text { Palestinian TV } \\
\text { addresses the } \\
\text { Palestinian division }\end{array}$} & Media & 172 & 3.52 & .822 & .498 & 249 & .619 \\
\hline & $\begin{array}{l}\text { Political } \\
\text { science }\end{array}$ & 79 & 3.46 & .814 & & & \\
\hline \multirow{2}{*}{$\begin{array}{l}\text { Role of the } \\
\text { Palestinian TV. }\end{array}$} & Media & 172 & 2.84 & .814 & -3.236 & 249 & .001 \\
\hline & $\begin{array}{l}\text { Political } \\
\text { science }\end{array}$ & 79 & 3.17 & .619 & & & \\
\hline \multirow[t]{2}{*}{ Priorities } & Media & 172 & 3.39 & .957 & .631 & 249 & .529 \\
\hline & $\begin{array}{l}\text { Political } \\
\text { science }\end{array}$ & 79 & 3.32 & .622 & & & \\
\hline \multirow[t]{2}{*}{ Confidence } & Media & 172 & 3.70 & .751 & -.351 & 249 & .726 \\
\hline & $\begin{array}{l}\text { Political } \\
\text { science }\end{array}$ & 79 & 3.74 & .660 & & & \\
\hline
\end{tabular}

Table (2) shows that there are significant statistical differences attributed to the impact of specialization on credibility, as the value of $(\mathrm{T})$ is $(-2.435)$. This value is statistically significant at less than (0.05) .Differences came in favor of political science at a mean of (2.61). It turns out that there are significant statistical differences (in the role of Palestinian $\mathrm{TV}$, as the value of (T) is -3.236). This value is statistically significant at less than (0.05). Differences came in favor of political science at a mean of (3.17). There is no significant statistical differences attributed to specialization in the variable of students' attitudes towards the way the Palestinian television addresses political division, as the value of (T) is (0.498). This value is not statistically significant at a level less than (0.05).The table also indicates that there is no effect for specialization on the priorities variable, as the value of (T) is $(0.631)$, and there are no significant differences in the confidence variable, as the value of $(\mathrm{T})$ is $(-.351)$. 


\section{Third: Place of Residence}

Table 3: shows Means, standard deviations, $(\mathrm{T})$ test for the impact of place of residence.

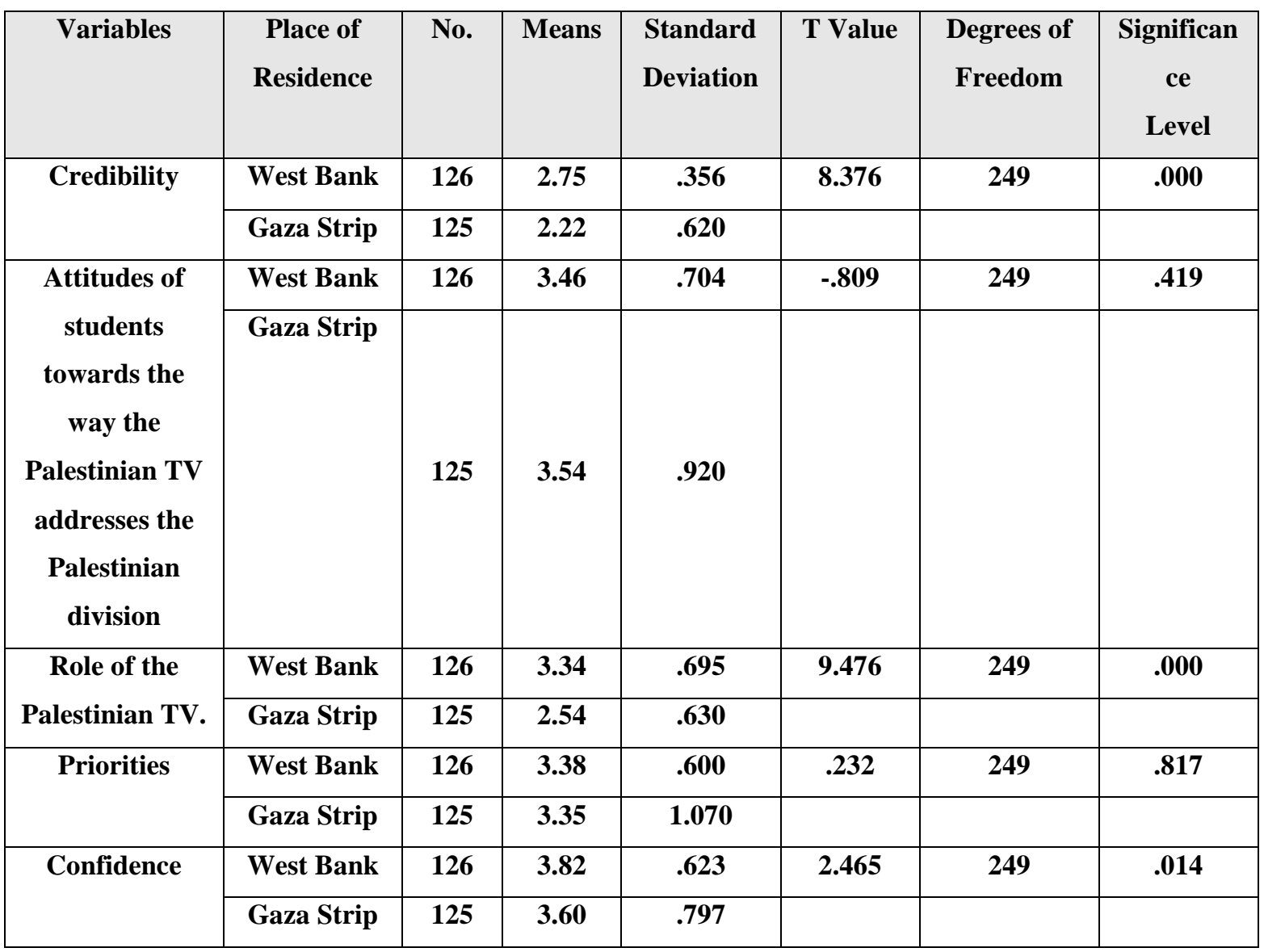

Table 3: shows that there are significant statistical differences attributed to the impact of place of residence and credibility, as the value of $(\mathrm{T})$ is (8.376).This value is statistically significant at a level less than (0.05). Differences came in favor of the West Bank at a mean of (2.75). The table also indicates that there are significant statistical differences in the role of Palestinian television as the value of $(\mathrm{T})$ is $(9.476)$. This value is statistically significant at less than (0.05). Differences came in favor of the West Bank with a mean of (3.34). There are no significant statistical differences in the variable of the Palestinian television way of addressing the political division as the value of (T) is (-.809), and in the variable of priorities the value of $(\mathrm{T})$ came (-.232). There are significant statistical differences in the confidence variable as the value of $(\mathrm{T})$ is $(2.465)$. ). This value is statistically significant at less than (0.05). The statistical significance was (-014). This means that there are significant statistical differences in the variable of credibility due to the place of residence. 


\section{Fourth: Political Affiliation}

Table 4: shows means, standard deviations, (T) test for the impact of political affiliation.

\begin{tabular}{|c|c|c|c|c|c|c|c|}
\hline Variables & $\begin{array}{c}\text { Place of } \\
\text { Residence }\end{array}$ & No. & Means & $\begin{array}{l}\text { Standard } \\
\text { Deviation }\end{array}$ & T Value & $\begin{array}{l}\text { Degrees of } \\
\text { Freedom }\end{array}$ & $\begin{array}{c}\text { Significance } \\
\text { Level }\end{array}$ \\
\hline \multirow[t]{2}{*}{ Credibility } & West Bank & 126 & 2.75 & .356 & 8.376 & 249 & .000 \\
\hline & Gaza Strip & 125 & 2.22 & .620 & & & \\
\hline \multirow[b]{2}{*}{$\begin{array}{c}\text { Attitudes of } \\
\text { students towards } \\
\text { the way the } \\
\text { Palestinian TV } \\
\text { addresses the } \\
\text { Palestinian } \\
\text { division }\end{array}$} & West Bank & 126 & 3.46 & .704 & -.809 & 249 & .419 \\
\hline & Gaza Strip & 125 & 3.54 & .920 & & & \\
\hline \multirow{2}{*}{$\begin{array}{c}\text { Role of the } \\
\text { Palestinian TV. }\end{array}$} & West Bank & 126 & 3.34 & .695 & 9.476 & 249 & .000 \\
\hline & Gaza Strip & 125 & 2.54 & .630 & & & \\
\hline \multirow[t]{2}{*}{ Priorities } & West Bank & 126 & 3.38 & .600 & .232 & 249 & .817 \\
\hline & Gaza Strip & 125 & 3.35 & 1.070 & & & \\
\hline \multirow[t]{2}{*}{ Confidence } & West Bank & 126 & 3.82 & .623 & 2.465 & 249 & .014 \\
\hline & Gaza Strip & 125 & 3.60 & .797 & & & \\
\hline
\end{tabular}

Table 4 shows that there are significant statistical differences attributed to the impact of political affiliation on the students attitude towards the way the Palestinian television addresses the Palestinian division, as the value of $(\mathrm{T})$ is $(-2.137)$. This value is statistically significant at less than (0.05).Differences came in favor of a partisan with a mean of (3.61). There are no significant statistical differences in the credibility variable, as the value of $(\mathrm{T})$ is (1.727) and (1.127) in the confidence variable.

Testing the second hypothesis: There is a significant statistical relation between the place of residence and political affiliation at the significance level $(\alpha<0.05)$ 
Table 5: Shows percentages, frequencies, chi square $\chi 2$ for the study sample according to their political affiliation (independent, partisan) in the West Bank and Gaza Strip).

\begin{tabular}{|c|c|c|c|c|c|c|}
\hline \multicolumn{2}{|c|}{ Place of Residence } & \multicolumn{3}{|c|}{ Political Affiliation } & \multirow{2}{*}{$\begin{array}{l}\text { Chi } \\
\text { Square } \\
\chi^{2}\end{array}$} & \multirow{2}{*}{$\begin{array}{l}\text { Significance } \\
\text { Level }\end{array}$} \\
\hline & \multicolumn{2}{|c|}{ Independent } & \multicolumn{2}{|c|}{ Partisan } & & \\
\hline $\begin{array}{l}\text { West } \\
\text { Bank }\end{array}$ & 75 & 42.4 & 102 & 57.6 & 7.388 & .007 \\
\hline $\begin{array}{l}\text { Gaza } \\
\text { Strip }\end{array}$ & 125 & 56.1 & & 43.9 & & \\
\hline
\end{tabular}

Table 5 refers to a correlative relation between the place of residence ( The West Bank and Gaza Strip) and the political affiliation (independent or partisan) as the value of Chi Square is $(7,388)$ and the level of significance 0.007.Differences were in favor of political affiliation (partisan in the West Bank and (independent) in the Gaza Strip. Thus the hypothesis is accepted.

Testing the third hypothesis: There is a significant statistical relation among the study variables (age, specialization, place of residence and political affiliation) and the ratio of exposure at the significance level $(0<0.05)$

Table 6: Shows percentages, frequencies, chi square $\chi 2$ for the study sample according to their age, and the exposure rate for the Palestinian TV.

\begin{tabular}{|c|c|c|c|c|c|c|}
\hline Variables & $\begin{array}{l}\text { Less than an } \\
\text { hour }\end{array}$ & 1-2 hours & 3-4 hours & $\begin{array}{l}5 \text { hours or } \\
\text { more }\end{array}$ & $\begin{array}{l}\text { Chi } \\
\text { square }\end{array}$ & $\begin{array}{l}\text { Significance } \\
\text { Level }\end{array}$ \\
\hline Age 17-20 & $\begin{array}{ll}16.6 & 27\end{array}$ & $23.3 \quad 14$ & 4-19 & $5-71.4$ & \multirow{4}{*}{35,12} & \multirow{4}{*}{0,000} \\
\hline $22-20$ & $\begin{array}{ll}57.7 & 94\end{array}$ & $51.7 \quad 31$ & $8-38.1$ & $1-14.3$ & & \\
\hline $25-23$ & $21.1 \quad 36$ & 20 & $14.3 \quad 3$ &....- & & \\
\hline 26 or more & $\begin{array}{ll}3.7 & 6\end{array}$ & 5 & $6-28.6$ & $1-14.3$ & & \\
\hline $\begin{array}{l}\text { Specializati } \\
\text { on } \\
\text { Media }\end{array}$ & $116-71.2$ & $\begin{array}{ll}63.3 & 38\end{array}$ & $12-57.1$ & $9-42.9$ & \multirow[t]{2}{*}{3,497} & \multirow[t]{2}{*}{0,321} \\
\hline $\begin{array}{l}\text { Political } \\
\text { science }\end{array}$ & $28,8-47$ & $36.7 \quad 22$ & $9-42.9$ & $1-14.3$ & & \\
\hline
\end{tabular}




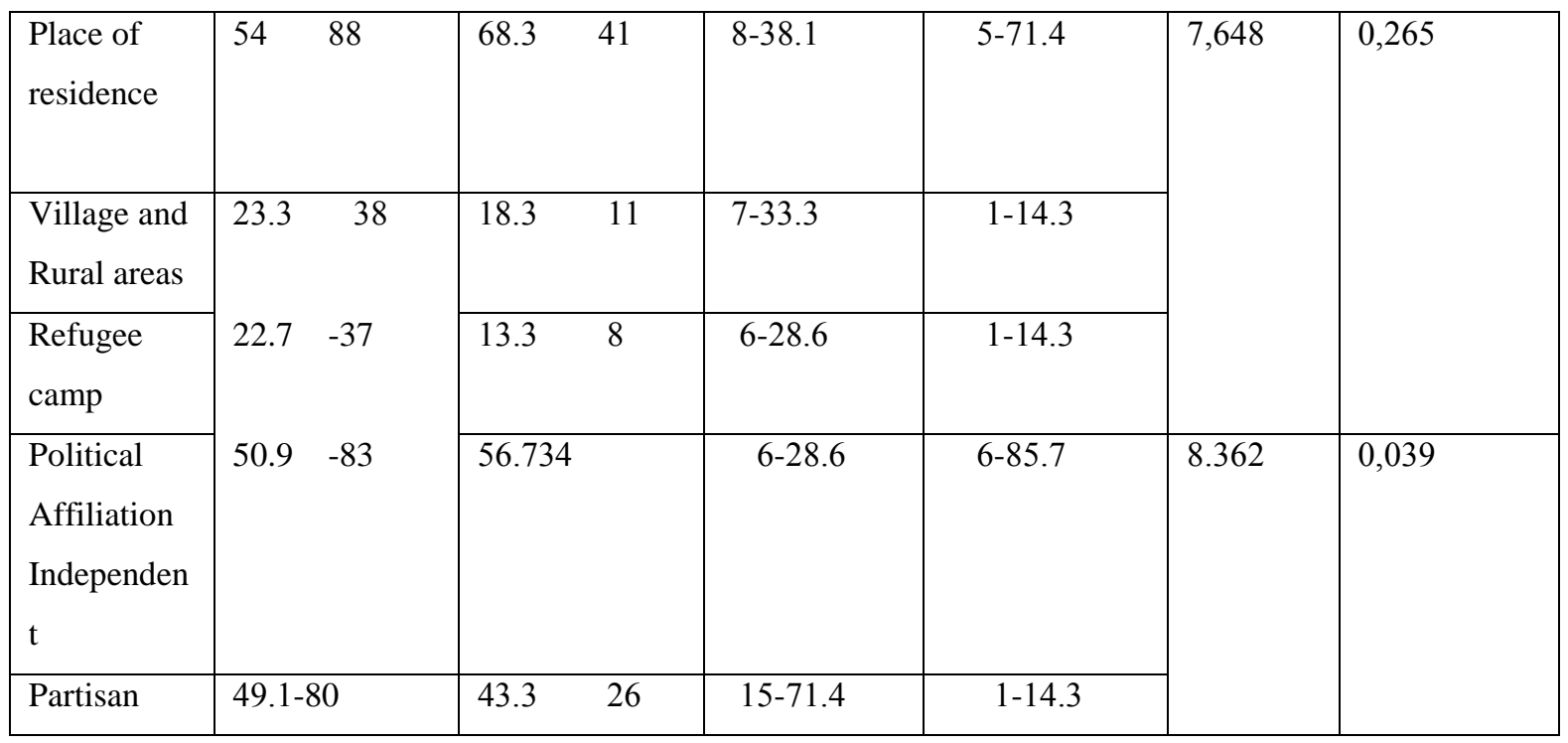

Table 6 shows that there is correlation between age, political affiliation and reliance on Palestinian television when exposed to contradictory information about the Palestinian division .Therefore, the hypothesis is accepted. The table also shows there is no correlation between dependence on Palestinian television when exposed to contradictory information about the Palestinian division according to specialization and place of residence. Therefore, the hypothesis is rejected

Testing the Fourth Hypothesis:

There is a statistical significant relation among the variables (age, specialization, place of residence, and political affiliation at the significance level $(0<0.05)$.

Table (7): shows percentages, frequencies for members of the study sample by age, specialization and place of residence, political affiliation and reliance on Palestinian television when exposed to contradictory information about the division.

\begin{tabular}{|c|c|c|c|c|c|}
\hline Variables & Rarely & Sometimes & Always & Chi square & $\begin{array}{c}\text { Significance } \\
\text { Level }\end{array}$ \\
\hline Age 17-19 & $18.6-24$ & $20.8-20$ & $23.1-6$ & \multirow{4}{*}{24,735} & \multirow{4}{*}{0,000} \\
\hline $22-20$ & $59.7-77$ & $52.1-50$ & $26.9-7$ & & \\
\hline $23-25$ & $20.2-26$ & $20.8-20$ & $19.2-5$ & & \\
\hline 26 or more & $1.6-2$ & $6.3-6$ & $30.8-8$ & & \\
\hline $\begin{array}{c}\text { Specialization } \\
\text { Media }\end{array}$ & $75.5-91$ & $67.7-65$ & $61.5-16$ & \multirow[t]{2}{*}{.862} & \multirow[t]{2}{*}{0,650} \\
\hline Political science & $29.5-38$ & $23.3-31$ & $38.5-10$ & & \\
\hline
\end{tabular}




\begin{tabular}{|c|c|c|c|c|c|}
\hline $\begin{array}{l}\text { Place of } \\
\text { residence }\end{array}$ & $54.3-70$ & $21.7-28$ & $24-31$ & 5,481 & 0,241 \\
\hline $\begin{array}{l}\text { Village and } \\
\text { Rural areas }\end{array}$ & $61.5-59$ & $25-24$ & $19.2-5$ & & \\
\hline Refugee camp & \multirow{2}{*}{$\begin{array}{c}24-31 \\
48.8-63\end{array}$} & $13.5-13$ & $30.8-8$ & & \\
\hline $\begin{array}{c}\text { Political } \\
\text { Affiliation } \\
\text { Independent }\end{array}$ & & $51.5-59$ & $26.9-7$ & 10,463 & 0,005 \\
\hline Party member & $51.2-66$ & $38.5-37$ & $73.1-19$ & & \\
\hline
\end{tabular}

Table No. (7) Shows a relationship between reliance on Palestinian television when exposed to contradictory information about the Palestinian division by place of residence, political affiliation at the significance level (0.005). So the hypothesis is accepted. The table indicates that there is no relationship between dependence on Palestinian television when getting information about the Palestinian division according to age, specialization, consequently; thus the hypothesis is rejected.

\section{Testing the Fifth Hypothesis}

There is significant statistical relation among the study variables (age, specialization, place of residence and political affiliation) and the reliance on the Palestinian television when obtaining information on the Palestinian division at the significance level $(0<0.05)$.

Table 8: Shows percentages, frequencies and chi square test for members of the study sample age, specialization and place of residence, political affiliation and reliance on Palestinian television when getting information about the Palestinian division.

\begin{tabular}{|c|c|c|c|c|c|c|}
\hline $\begin{array}{c}\text { Data on the Division } \\
\text { Variables }\end{array}$ & Rarely & Som & & Always & $\begin{array}{c}\text { Chi } \\
\text { square }\end{array}$ & $\begin{array}{c}\text { significance } \\
\text { Level }\end{array}$ \\
\hline Age $17-19$ & $\begin{array}{r}15- \\
13.5\end{array}$ & 24.1 & 27 & 28.6 & \multirow[t]{4}{*}{9,796} & \multirow[t]{4}{*}{0,134} \\
\hline $22-20$ & $64-57.7$ & 52.7 & 59 & $\begin{array}{ll}17.9 & 20\end{array}$ & & \\
\hline $23-25$ & $26-23.4$ & 17.9 & 20 & 17.9 & & \\
\hline 26 or more & $6-5.4$ & 5.4 & 6 & 14.3 & & \\
\hline $\begin{array}{c}\text { Specialization } \\
\text { Media }\end{array}$ & $80-73$ & 68.8 & 77 & 50 & \multirow[t]{2}{*}{5,476} & \multirow[t]{2}{*}{0,056} \\
\hline Political science & $30-27$ & 31.3 & 35 & $\begin{array}{ll}50 & 14\end{array}$ & & \\
\hline
\end{tabular}




\begin{tabular}{|c|c|c|c|c|c|c|c|}
\hline Place of residence: City & $\begin{array}{r}72- \\
64.9\end{array}$ & 53.6 & 60 & 35.7 & 10 & \multirow[t]{3}{*}{13,762} & \multirow[t]{3}{*}{0,008} \\
\hline Village and Rural areas & \multirow{3}{*}{$\begin{array}{c}15-13.5 \\
24-21.6 \\
50-45\end{array}$} & 26.8 & 30 & 42.9 & 12 & & \\
\hline Refugee camp & & 19.6 & 22 & 21.4 & 6 & & \\
\hline $\begin{array}{l}\text { Political Affiliation } \\
\text { Independent }\end{array}$ & & 60.7 & 68 & 39.3 & 11 & 7,329 & 0,026 \\
\hline Partisan & $61-55$ & 39.3 & 44 & 60.7 & 17 & & \\
\hline
\end{tabular}

Table 8 shows a relationship between dependence on the Palestinian television when exposed to contradictory information about the Palestinian division according to place of residence, political affiliation at the significance level (0.05) .Thus the hypothesis is acceptable. The table also shows that there is no relationship between dependence on the Palestinian TV when getting information about the Palestinian division according to age and specialization, and so the hypothesis is rejected.

\section{Testing the Sixth Hypothesis}

There is a significant statistical relation among the study variables (age, specialization, place of residence, and political affiliation) and the reliance on the Palestinian television in understanding topics related to the political division at $(0<0.05)$.

Table (9): Shows percentages, frequencies and chi square test for the study sample's age, specialization, place of residence, political affiliation and reliance on the Palestinian television in understanding topics concerning the division.

\begin{tabular}{|c|c|c|c|c|c|c|c|c|}
\hline $\begin{array}{c}\text { Data on the division } \\
\text { Variables }\end{array}$ & \multicolumn{2}{|c|}{ Rarely } & \multicolumn{2}{|c|}{ Sometimes } & \multicolumn{2}{|c|}{ Always } & $\begin{array}{c}\text { Chi } \\
\text { square }\end{array}$ & $\begin{array}{c}\text { significanc } \\
\text { e Level }\end{array}$ \\
\hline Age 17-19 & 19.5 & 26 & 20.4 & 19 & 20 & 5 & \multirow{4}{*}{15.873} & \multirow{4}{*}{0,014} \\
\hline $22-20$ & 56.4 & 75 & 52.7 & 49 & 40 & 10 & & \\
\hline $23-25$ & 18.8 & 25 & 23.7 & 22 & 16 & 4 & & \\
\hline 26 or more & 5.3 & 7 & 3.2 & 3 & 24 & 6 & & \\
\hline $\begin{array}{c}\text { Specialization } \\
\text { Media }\end{array}$ & 71.4 & 95 & 66.7 & 62 & 60 & 15 & 1.511 & 0,470 \\
\hline Political science & 28.6 & 38 & 33.3 & 31 & 40 & 10 & & \\
\hline Place of residence: City & 54.9 & 73 & 61.3 & 57 & 48 & 12 & & 0,307 \\
\hline Village and Rural areas & 25.3 & 27 & 24.7 & 23 & 28 & 7 & 4.818 & \\
\hline Refugee camp & 24.7 & 33 & 14 & 13 & 24 & 6 & & \\
\hline
\end{tabular}




\begin{tabular}{|c|ccc|cc|cc|c|c|}
\cline { 1 - 3 } $\begin{array}{c}\text { Political Affiliation } \\
\text { Independent }\end{array}$ & 52.6 & 70 & 55.9 & 52 & 28 & 7 & 6.319 & 0,042 \\
\hline Partisan & 47.4 & 63 & 44.1 & 41 & 72 & 18 & & \\
\hline
\end{tabular}

Table (9) shows a relationship between reliance on Palestinian television in understanding the topics related to the division according to age, political affiliation at (0.05), and so the hypothesis is accepted. The table also indicates that there is no relationship between dependence on Palestinian television in understanding the topics related to the division according to specialization, place of residence and so the hypothesis is rejected.

\section{Testing the Seventh Hypothesis:}

There is a significant statistical difference at the level of confidence in the television as a source of information on the issue of division according to sex. To test this hypothesis, means and standard deviations were calculated and the independent sample $\mathrm{T}$ test was administered.

Table (10): Shows means, standard deviations and T-test between the levels of confidence in television as a source of information on the issue of division according to sex.

\begin{tabular}{|l|l|l|l|l|l|l|}
\hline Sex & Number & Mean & $\begin{array}{l}\text { Standard } \\
\text { Deviation }\end{array}$ & $\begin{array}{l}\text { Value of } \\
\text { T }\end{array}$ & $\begin{array}{l}\text { Degree of } \\
\text { Freedom }\end{array}$ & $\begin{array}{l}\text { significance } \\
\text { Level }\end{array}$ \\
\cline { 1 - 6 } Male & 140 & 1.814 & 1.814 & -.412 & 249 & .681 \\
\cline { 1 - 5 } Female & 111 & 1.536 & 1.536 & & & \\
\hline
\end{tabular}

Table (10) shows that there is no significant statistical difference between the levels of confidence in the television as a source of information on the issue of division, according to sex, therefore the hypothesis is rejected and the alternative hypothesis was accepted.

\section{Discussion of the Findings}

The results of the study showed that Palestinian television has a role in the Palestinian division, as the item (Palestinian TV deepens the division) ranked first with a mean of (3.80). The Television treatment of the Palestinian political division is negative. The results of the study showed no significant statistical differences attributed to the impact of sex on credibility, attitudes, role of television, priorities and confidence variables, where the significance level was less than (0.05).There are significant statistical differences attributed to 
the impact of place of residence, and credibility, where the statistical function was (.000). The differences came in favor of the West Bank at a mean of (2.75). There is a significant statistical relation among the study variables (age, specialization, place of residence and political affiliation) and the rate of exposure to the TV at $(\alpha<0.05)$

\section{Recommendations}

In the light of the findings, the researchers recommend that:

1. Programs offered by the Palestinian television should vary to meet the needs of the Palestinian viewers.

2. TV program presenters should be qualified to make viewers of the Palestinian space channel watch it more.

3 Palestinian satellite channels should be promoted and its importance should be emphasized to the Palestinian viewers.

4. The Palestinian channel should present local issues of concern to the Palestinian citizen, especially the political division. 


\section{References}

Abdel-Hamid, Mohammed,The Public Studies in the Media Researches, the World of Books, Cairo, 1993, pp. 102

Abdullah, Abdul Rahim (2003), The Impact of the Israeli Media on Trends and Opinions of Media Students at Birzeit University.: "The corruption of the Palestinian Authority as a Model," M.A. Birzeit University, Faculty of Arts, Department of Media, from Media Studies Book by SamihShabib, 2004, pp. 181-196

AbedRabbo, Raed Mohammed, Introduction to Cinema and TV, Janadria House of Publishing and Distribution, Ed.1, 2009, p 115-116

Al Dalow , Jawad, (2006), Public Attitudes Towards the Means of Communication and its Tactics Used in Al-Aqsa Intifada, the Islamic University Journal (Humanities Series) Vol. 14, 1st Issue , P.1-56.

AL- Jawhari, Mohammed et al, Sociology and the Study of Media and Communication, Dar Al Ma'refeh University Press , ed., 1992, p 293

Al- Mashagbeh, Bassam Abdul-Rahman, Parliamentary and Political Media, Jordan, Dar Osama for Publication and Distribution, i 1, 2011, p 69

Al- Mashgbeh, Bassam Abdul-Rahman, The Media Theories, Jordan, Osama Publishing House, ed. 1, (2001), pp. 96

AL- Qudah, Mohammed Falah, The Factors Influencing the Birth and Evolution of Arab Television, Yarmouk Researches, Irbid - Jordan 'Volume 25, Issue 1, 1998, p 93. Al- Saree, Fouad Ahmed, Media Origin and Evolution, Jordan, Osama Publishing and Distribution House, ed.1, 2011, p 342

AL- Talib, Mousa (2011), The Role of the Media in Promoting the Palestinian National Unity among University Female Students in the Gaza Strip, Al-Azhar University in Gaza magazine, a Series of Human Sciences, Vol.13, Issue 1.

Al-Dulaimi, Abdul Razak Mohammed, Arab Media, the Pressures of the Present and the Challenges the Future, Jordan, Dar AL-Masseera for publication and distribution, ed. 1, 2011, p 94

AL-Dusooki, Abdo Ibrahim, TV and Development, Egypt, Dar AL Wafa' for the World of Printing and Publishing, Ed. 1, 2004, p 221-222

Al-sdouki, Muhammad, the TV Function in the Arab Community, Civilized Dialogue, 20/03/2012: http://www.ahewar.org/debat/show.art.asp?aid=75388 
Farra, ShawkiYahya, (2010), the Impact of the Palestinian Satellite TV on the Palestinian Situation, "the Gaza War Model," M.A Thesis in Information and Communication, the Arab Open Academy in Denmark, Department of Information and Communication.

Hassan EmadMakkawi, Laila AL Sayyed, Communication and Contemporary Theories ,(Cairo: The Egyptian Lebanese House, Ed. 2, (2003), pp. 74-76

Hassan, Fibansé, (2000), Lectures in Social Psychology, Faculty of Arts, Soohaj, South Valley University, p 81

Malkawi, Hassan, Theories of Media, Cairo, Arab Publishing and Distribution House, (2009), pp. 216

Melvin's, Daffler and Sandra Paul Rokich (1994) Theories of Media, Translated by

Mohammad Naji Al Jawhar, Cairo Dar AL- Amal for Publishing and Distribution, ed. $1, \mathrm{p} 22-23$

Melvin's.Daffler and Sandra Paul Rokich_(1993) Theories and Media, Translated by Kamal Raouf, Cairo International Publishing and Distribution, Ed. 1, p 65-67

Muhanna, Mohamed Nasr, Political Media Between Theory and Practice, Alexandria, Dar al Wafa' Printing World and Publishing, ed.1, 2007, p 249

Muntasser, Hamdan, (2012), The Role of Media in Promoting the Palestinian Division, Palestine Satellite Channel and al-Aqsa Model, Issued by the Palestinian Center for Development and Media Freedom.

Previous Source, Al-Dulaimi, The Arab Media Pressures of the Present and Future Challenges, p 197

Sadeq, Mohamed Adel, The Press and Crisis Management, Theoretical -Practical Introduction, Cairo, Dar Al Fajr for Publication and Distribution, Ed. 1, (2007), pp. 52 Sayyed .Fouad Al- Bahi, Abdul RahmanSa'ad, Social Psychology, Cairo, Arab Thought House, p 258-259'

SodqiMousa (2009), Trends of Palestinian University Students about Media Coverage of Palestine TV Channel for Internal Events- Birzeit University model; M.A. Thesis; Department of Media, Faculty of Arts, University of Middle East Graduate Studies ThabitMalkawi, Media and Societal Shifts, Political Media on the Arab Satellite Channels, the University of Yarmouk -Irbid, Faculty of Information, 23-25 October 2011 
Toman, Amal, (2010), The Palestinian Media and its Impact on the Ppolitical Division (20062009), M.A. Thesis, Faculty of Economics and Administration, Political Science Program, Al-Azhar University, Gaza. 